\title{
Analysis of Problem Solving Ability Judging from the Ethnicity of Junior High School Students on Social Arithmetic Materials in Singkawang City West Kalimantan
}

\author{
Tya Nur Sukmawati", Nurul Husna, Rika Wahyuni \\ STKIP Singkawang - West Kalimantan \\ *Corresponding Author. Email: nursukmawaticahayap@gmail.com
}

\begin{abstract}
This study aims to analyze; 1) the level of problem-solving ability of ethnic Chinese students; 2) the level of problem-solving ability of ethnic Malay students; 3 ) Students' problem-solving abilities based on the type of questions; 4) Differences in problem-solving abilities of ethnic Malay and Chinese students. This research method uses qualitative research. Students of ethnic Malay and ethnic Chinese class VIII at SMPN 1 Singkawang are the samples of this study. The problem-solving ability test was used as a research instrument. The data analysis technique uses an interactive (qualitative) model, namely by reducing data, presenting data, and drawing conclusions. Based on the results of this study it can be concluded; 1) The problem-solving ability of ethnic Chinese students on social arithmetic material is in the medium criteria; 2 ) The problemsolving ability of ethnic Malay students on social arithmetic material is in the medium criteria; 3) Based on the type of question, ethnic Malay and Chinese ethnic students are more able to work on question 1 than questions number 2 and $3 ; 4)$ there is no significant difference between ethnic Chinese and ethnic Malay students in their problem-solving abilities. Overall, the findings in this study indicate that there is no difference in problem-solving abilities between ethnic Chinese and ethnic Malay students. However, the indicator determines the plan: writing the formula that will be used in answering the questions of ethnic Malay students is superior to ethnic Chinese students.
\end{abstract}

\section{Article History}

Received: 29-06-2021

Revised: 05-08-2021

Accepted: 06-11-2021

Published: 11-12-2021

Key Words:

Problem Solving

Ability, Math

Learning, Ethnic

Chinese, Ethnic

Malays.

How to Cite: Sukmawati, T., Husna, N., \& Wahyuni, R. (2021). Analysis of Problem Solving Ability Judging from the Ethnicity of Junior High School Students on Social Arithmetic Materials in Singkawang City West Kalimantan. Jurnal Kependidikan: Jurnal Hasil Penelitian dan Kajian Kepustakaan di Bidang Pendidikan, Pengajaran dan Pembelajaran, 7(4), 968-980. doi:https://doi.org/10.33394/jk.v7i4.3920

d. https://doi.org/10.33394/jk.v7i4.3920

This is an open-access article under the CC-BY-SA License.

\section{Introduction}

Problem solving ability is defined as an activity that requires a high level of intelligence to achieve a goal (Zulfah, 2020). Imiyana (2018) states that problem-solving skills can help students achieve goals in learning and real problems. Therefore, the problem solving ability is an essential ability to be applied in learning mathematics (Rofoqoh, 2015). Afandi (2020) states that problem-solving ability is the process of finding a solution to a problem with existing knowledge which will then develop into new knowledge through the plans they make. Khalid, et al (2020) also revealed the importance of problem-solving skills as follows : "Problem solving is also considered as one of the most important skills in the 21 st century that a student should possess because of the many advantages that a good problem solver would enjoy in everyday life and in the workplace. Therefore, problem solving should be considered an integral part of mathematics learning and it should not be viewed as exercises that students perform at the end of every topic from the school textbook".

Therefore, with the problem solving skills, it is expected that students can be skilled and trained in solving problems using these ability indicators (Mariyam, P \& Wahyuni, 2018). The indicators of problem-solving ability in question are 1) writing down what is known and asked from the problems provided, 2) writing down the steps to solve the 
problem, 3) carrying out the steps that have been written previously, and 4) ensuring the results obtained are true (Khakim, 2016). These indicators are in line with indicators according to Polya (Prabawa \& Zaenuri, 2017) namely 1) understanding what is meant by the problem, 2) making a resolution strategy, 3) using the strategy to solve problems, and 4) checking the correctness of the results obtained. So it can be concluded that the indicators of problem-solving ability are 1) writing down important information and what is being asked, 2) determining the plan/formula that will be used in finding solutions, 3) operating the previously written plan/formula, and 4) rechecking whether the answers from the solution is correct.

Problem solving skills are useful for students to explore, observe, experiment, research, and determine strategies to solve the problems they face. And students can see the relevance between learning and the real world. Agree with Bernard, et al (2018) which states that "problem-solving is a learning approach that optimally involves active students that allow students to explore, observe, experiment, and investigate. Besides Bernard, Ilmiyana also revealed that problem solving skills are useful for students. With problem solving skills, students can see the harmony of mathematics with the real world (Ilmiyana, 2018). Utami \& Wutsqa (2017) also states "with problem solving students will learn to develop appropriate strategies to solve the problems they face.

Learning mathematics in schools requires problem-solving skills. With problem solving skills, it can simplify the lives of students now and in the future (Akbar, et al, 2018). Meanwhile, according to Ruseffendi (Islamiah, et al, 2018) not only in mathematics, in other sciences and daily activities problem-solving abilities are also useful for those who apply them. In mathematics problem solving is used to find other ways to solve problems sensibly and create high curiosity (Fajriah \& Suryawati, 2016). Based on the above opinion, in learning mathematics, solving ability is used to solve a scientific problem logically. With logical thinking, this ability can be applied in other learning and the real world. In everyday life, problem-solving skills can also be applied. In real life, to realize a desire, you can use problem-solving abilities (Ilmiyana, 2018). In line with Rofiqoh (2015) problem solving is important in the goals of mathematics education because in everyday life humans can never be separated from problems. Problems must be found a way out by humans themselves if they don't want to be defeated by life. Based on the opinion above, so that students can find solutions to a problem and achieve what they want in real life they must have problemsolving skills.

The learning objectives state that problem-solving skills must be possessed by students as stated in NCTM (2000) which reads The next Five Standards address the processes of problem-solving, reasoning and proof, connections, communication, and representation. In Indonesia, the problem solving ability is a learning goal in primary and secondary schools as stated in (Permendikbud, 2016). In addition to the learning process, problem-solving skills are also very necessary in mathematics as revealed by Davis and McKillip (in Haryani, 2011). Due to its enormous influence both in learning and in everyday life, students need to have problem solving skills. Based on the explanation, with the many uses of problem-solving abilities, students must have these abilities. With these abilities, students can explore, observe, experiment, investigate and determine strategies to solve the problems they face. And students can see the relevance of learning to the real world. In addition, it will grow a serious attitude in learning, directed and able to use logical reason in solving problems. Therefore, it is hoped that by applying problem-solving skills to students themselves, the ranking of mathematics learning at the national and international levels can increase. However, based on the results of existing research that students' problem solving 
abilities are still low. Bernard, et al (2018) stated that based on the achievement of four indicators of students' problem solving abilities, they were still lacking. This is in line with the opinion of Akbar, et al (2018) which states that problem solving abilities are in the low category with the average student understanding a little on the first indicator and not at all on the fourth indicator. In line with the previous opinion of all students studied, only one student could answer questions using problem-solving indicators (Putra, et al, 2018).

The low problem solving ability is also experienced in one of the junior high schools in Singkawang City, namely SMPN 1 Singkawang, West Kalimantan. Based on the results of an interview with one of the mathematics teachers at the school who said that students' problem-solving abilities were low. This was because students were only able to work on routine questions rather than questions that contained_problem-solving abilities. In addition to interviews, the results of the pre-research also showed that the problem-solving abilities of students at SMPN 1 Singkawang are still relatively low. Pre-research results showed that students still find it difficult to solve problems that contain problem-solving abilities. In the indicator determining the method/formula to solve the problem, the majority of students could answer correctly so that on the indicator students could be said to understand the command of the question given. However, on questions containing indicators to identify questions, the majority of students did not answer correctly. From the answers obtained, it can be seen that $64 \%$ of students did not understand the questions given.

The bad impact of low student problem solving abilities is that students will have difficulty in finding solutions to problems related to real-life (Lestanti, 2015). Another bad impact is that compared to other subjects, mathematics has the lowest achievement of national exam results for Ciamis Regency (Utami \& Wutsqa, 2017). Based on the facts, it can be concluded that problem-solving skills must be further improved because it will harm students and learning mathematics. Mestre (in Astuti \& Hudiono, 2009) states that culture influences how to learn mathematics. Comprehensive efforts to develop mathematical abilities must take into account cultural, linguistic, socioeconomic, and attitudinal factors. Shipman \& Shipman (in Astuti \& Hudiono, 2009) state that the cognition style of similar ethnic groups is better than groups of various ethnicities. This shows that there is an influence of ethnic groups on students' cognitive activities.

At SMPN 1 Singkawang, one class consists of several ethnic groups, this will affect students' cognitive activities, one of which is problem-solving ability. The same thing was also expressed by Astuti \& Hudiono (2009) that the influence of ethnic groups on the development of mathematical abilities must also pay attention to cultural, language, socioeconomic, and attitude factors. Where the capture power of each student is different which is influenced by the cultural (ethnic) differences they have. In Singkawang City, West Kalimantan Province, in particular, there are three major ethnic groups, namely Chinese, Dayak, and Malay. Where ethnic Chinese are the most ethnic living in Singkawang (Suprapto \& Kariadi, 2017). This research focuses on the ethnic Chinese and Malays. The Chinese ethnicity is one of the ethnic groups in Indonesia. Where ethnic Chinese is one of several varieties of ethnic Chinese descent. As we know that the majority of ethnic Chinese are very good at trading and doing business. According to Burhan, the Chinese ethnicity dominates the economy and holds a lot of power in Medan and according to Khoiri, the Chinese ethnicity controls the economy and economic transactions in border areas (in Sari \& Dewi, 2020). This also applies in Singkawang, where Singkawang is one of the cities where the majority of the population is ethnic Chinese. While one of the indigenous groups in Indonesia is the Malay ethnic. Where ethnic Malays are widely spread on the islands of Sumatra and Kalimantan. In the Malay ethnic group in Kalimantan, there are several clumps, including the 
Pontianak Malay tribe, the Sambas Malay tribe, the Kuai tribe, the Banjar tribe, and many more. The Malay in Sepandak which is part of the Sambas Malay can be proven from the language used. The language spoken by the Malays here is the Sambas language. The vocabulary learned from the speakers here shows similarities to the Malay language spoken by the Sambas Malays. Likewise with the sound characteristic, namely the sound [ ] at the end of the word which is parallel to the sound [a], shows similarities to the characteristics that are well known in Malay Sambas (Yusriadi, 2015). In addition to the distinctive features and traditions of each ethnicity, according to Hammond (2000) "every culture seems to have counted, composing, and other mathematical foundations that seem to imply something basic and strong about the foundations of mathematics. This opinion is supported by research conducted by Astuti \& Hudiono (2009) which states that there is a difference in the average of basic abilities and mathematical problem-solving.

This study aims to analyze; 1) the level of problem-solving ability of ethnic Chinese students; 2) the level of problem-solving ability of ethnic Malay students; 3) Students' problem-solving abilities based on the type of questions; 4) Differences in problem-solving abilities of ethnic Malay and Chinese students.

\section{Research Method}

The research method used is qualitative research. Qualitative research is a research method based on philosophy with the researcher as the key to this research and the acquisition of research results emphasizes more on meaning (Sugiyono, 2017). Sudjana \& Ibrahim (2007) also revealed that qualitative research is research that aims to analyze and describe an event or events either individually or in groups. While the type of research uses descriptive. According to Damayanti \& Supriyadi (2016), the relationship between descriptive research and a qualitative approach is where research is carried out clearly and systematically to predict a phenomenon that occurs based on data in the field. A total of 224 class VIII students of SMPN 1 Singkawang became the population in this study. The sample in this study was 32 students consisting of 16 ethnic Malay students and 16 ethnic Chinese students. Where the sampling technique is using random sampling.

To obtain the required data, structured tests and interviews were used as instruments in this study. The tests are given in the form of easy questions that contain problem-solving abilities so that it is easy to analyze students' abilities. Meanwhile, to analyze the test results, a calculation technique was used using the following formula.

$$
N=\frac{\text { score obtained }}{\text { maximumscure }} \times 100
$$

After obtaining student scores for each indicator, then grouping students based on the percentage of test scores with the following criteria.

\begin{tabular}{cl} 
Table 1. Criteria for Problem Solving Ability \\
\multicolumn{1}{c}{ Test Score Percentage } & Criteria \\
\hline$X \geq(\bar{x}+S D)$ & High \\
$(\bar{x}-S D)<X<(\bar{x}+S D)$ & Medium \\
$X \leq(\bar{x}-S D)$ & Low \\
\hline
\end{tabular}

Furthermore, groups based on criteria can be analyzed and concluded the problemsolving abilities of Chinese and Malay ethnic students on social arithmetic material. The data analysis used in this research is using the Miles and Huberman model where the analysis is carried out effectively and continuously until the final result is obtained (Meleong, 2005). Stages of data analysis involved 1) Data reduction, namely selecting and focusing on 
important things that have been obtained from the results of the problem-solving ability test, 2) Data presentation, after the data are reduced then the data are presented in a structured and categorized form, and 3) Concluding, the data that have been presented allows researchers to conclude.

\section{Results and Discussion}

Test questions containing problem-solving skills were given to 32 students of class VIII SMPN 1 Singkawang with details of 16 Chinese ethnic students and 16 Malay ethnic students to obtain the actual data. The research results will be discussed by the research objectives. The results and discussion in this study are:

1) The Level of Problem Solving Ability of Ethnic Chinese Students on Social Arithmetic Materials

Table 2. Description of the Problem Solving Ability of Ethnic Chinese Students

\begin{tabular}{|c|c|c|}
\hline Percentage & Ability Level & Description \\
\hline $12,5 \%$ & High & $\begin{array}{l}\text { Students can answer questions } \\
\text { correctly by using four stages of } \\
\text { problem-solving skills. }\end{array}$ \\
\hline $68,75 \%$ & Medium & $\begin{array}{l}\text { Students perform all stages of } \\
\text { problem-solving skills but are not } \\
\text { optimal in answering questions. And } \\
\text { some don't carry out the re-check } \\
\text { stage. }\end{array}$ \\
\hline $18,75 \%$ & Low & $\begin{array}{l}\text { In this criterion, all students do not } \\
\text { carry out the last stage of problem- } \\
\text { solving skills, namely checking the } \\
\text { correctness of answers. }\end{array}$ \\
\hline
\end{tabular}

From the table above, the overall problem-solving abilities of students obtained the description results that the high criteria for ethnic Chinese students were $12.5 \%$ of students were able to perform all stages of problem-solving abilities. While the description for students with moderate criteria is $68.75 \%$ students can do all stages of problem-solving skills, it's just that the answers they write are not quite right. And for students with low criteria, $18.75 \%$ of students did not carry out the stage of checking the correctness of the answers. It is described in detail as follows.

a) Ethnic Chinese With High Criteria

Overall, ethnic Chinese students with high criteria were able to work on questions that included problem-solving abilities. Ethnic Chinese students with high criteria can answer questions with indicators of understanding the problem by writing information from the questions in full on each question number. Ethnic Chinese students with high criteria are also able to answer questions with indicators to determine plans by writing formulas or formulas that will be used to answer questions from the questions correctly. Furthermore, ethnic Chinese students with high criteria can answer questions with indicators of implementing according to the plan, namely by writing down the steps to solve the problem according to the formula that has been written previously with the right calculation results.

Overall, ethnic Chinese students with high criteria were able to work on questions that included problem-solving abilities. Ethnic Chinese students with high criteria can answer questions with indicators of understanding the problem by writing information from the questions in full on each question number. Ethnic Chinese students with high criteria are also able to answer questions with indicators to determine plans by writing formulas or 
formulas that will be used to answer questions from the questions correctly. Furthermore, ethnic Chinese students with high criteria can answer questions with indicators of implementing according to the plan, namely by writing down the steps to solve the problem according to the formula that has been written previously with the right calculation results.

b) Ethnic Chinese with Medium Criteria

Chinese ethnic students with moderate criteria can answer questions that contain indicators of understanding the problem by writing down the information contained in the questions correctly and regularly. Chinese ethnic students with moderate criteria are not optimal on the indicators of planning and carrying out according to plan. It can be seen from the answers written on the indicators of preparing plans for ethnic Chinese students with the criteria of being writing formulas and directly solving problems. While the indicators run according to the plan of ethnic Chinese students with moderate criteria, only writing the final results.

And finally, on the indicator, re-examine Chinese ethnic students with the criteria of not answering at all. This shows that ethnic students with moderate criteria do not master this indicator. Students with moderate criteria are only able to understand the problem indicators, and are less than optimal in planning, determining plans and carrying out accordingly. Ethnic Chinese students with moderate criteria did not master the indicators to re-examine. This is in line with the opinion of Akbar (2018) which states that the ratio has the ability to solve problems on indicators of understanding problems and planning better than indicators of running according to plan and checking again. Therefore, students based on the criteria were not optimal in carrying out the problem-solving ability stage according to Polya.

c) Ethnic Chinese With Low Criteria

Ethnic Chinese students with low criteria on the indicator of understanding the problem look less mastered, it can be seen from the student's answer that is rewriting the question command. This shows that students do not master the indicators of understanding the problem. In the questions that contain indicators for determining the plans of ethnic Chinese students with low criteria, write formulas and immediately solve problems, but the results obtained are not correct. And on the questions that contain indicators, carry out according to the plan of ethnic Chinese students with low criteria, write formulas and directly solve problems, but the formulas used are different from questions that contain indicators for planning. And the last question that contains indicators is to re-examine Chinese ethnic students with the criteria of not answering.

Thus, ethnic Chinese students with low criteria do not master problem solving skills based on Polya's theory. In the indicators of understanding the problem, making plans and carrying out according to the plan students answer the questions but the answers written are not correct. On the indicator of re-examining the students did not understand at all. This is supported by the opinion of Akbar (2018) which states that the problemsolving ability of the indicators of implementing according to plan and re-checking is low.

2) Level of Problem Solving Ability of Ethnic Malay Students on Social Arithmetic Materials 
Table 3. Description of the Problem Solving Ability of Ethnic Malay Students

\begin{tabular}{lll}
\hline $\begin{array}{l}\text { Percentage of } \\
\text { students }\end{array}$ & Criteria & \multicolumn{1}{c}{ Description } \\
\hline $12,5 \%$ & High & $\begin{array}{l}\text { Students carry out all stages of } \\
\text { problem-solving abilities but are less } \\
\text { than optimal at the stage of checking } \\
\text { the correctness of answers. } \\
\text { Students carry out all stages of } \\
\text { problem-solving abilities, but only } \\
\text { some students can carry out the stage } \\
\text { of checking the correctness of } \\
\text { answers even though they are not } \\
\text { optimal. } \\
\text { In this criterion, none of the students } \\
\text { carried out the stage of checking the } \\
\text { correctness of the answers and at } \\
\text { other stages, they were not optimal in } \\
\text { doing so. }\end{array}$ \\
& Medium &
\end{tabular}

From the table above, the overall problem-solving ability of students obtained the results of the description, namely the high criteria for ethnic Malay students of $12.5 \%$. Students carried out all stages of problem-solving abilities but were less than optimal at the stage of checking the correctness of the answers. While the description for students with moderate criteria is $75 \%$. Students carry out all stages of problem-solving abilities, but only some students can carry out the stage of checking the correctness of answers even though they are not optimal. And for students with low criteria of $12.5 \%$ students are only able to carry out 3 stages of problem-solving skills and do not carry out the stage of checking the correctness of answers. It is described in detail as follows.

a) Ethnic Malay With High Criteria

Overall, Malay ethnic students with high criteria were able to work on questions that included problem-solving abilities. Ethnic Malay students with high criteria can answer questions with indicators of understanding the problem by writing information from the questions in full on each question number. Malay ethnic students with high criteria are also able to answer questions with indicators to determine plans by writing formulas or formulas that will be used to answer questions from the questions correctly. Furthermore, ethnic Malay students with high criteria can answer questions with indicators of implementing according to the plan, namely by writing down the steps to solve the problem according to the formula that has been written previously with the right calculation results.

And finally, ethnic Malay students with high criteria did not understand the questions that contained indicators for checking students again, it could be seen from the students' answers that they only answered one question, while for the other two questions, students only confirmed their previous answers by writing "okay" answers. Malay ethnic students with high criteria are only able to answer one complete question using the problemsolving ability stage according to Polya. As for the other two questions, students are only able to reach the third stage, namely understanding the problem, making plans, and carrying out according to the plan. And did not complete the fourth stage which is rechecking. 
b) Ethnic Malay with Medium Criteria

Malay ethnic students with moderate criteria answered all questions containing indicators of understanding the problem by writing down the information contained in the questions correctly, briefly, and clearly. Ethnic Malay students with moderate criteria are answering questions 1 and 3 which contain indicators of making inappropriate plans where students write formulas and immediately solve problems. And it is only true in question number 2 which also contains indicators for determining the student's plan to write the right answer, namely the formula and steps to solve the problem. In the indicators of running according to the plan, ethnic Malay students with the criteria are answering correctly according to the plan that has been previously written only on question number 2 while in questions number 1 and 3 students write the solution using a different formula than previously written but the final result obtained is correct.

And finally, on the indicator of re-examining Malay ethnic students with the criteria of not answering at all. This shows that ethnic Malay students with moderate criteria do not master this indicator. Malay ethnic students with moderate criteria are only able to understand the problem on indicators and are less than optimal on indicators of determining plans and carrying out according to plans. Ethnic Malay students with moderate criteria did not master the indicators to re-examine. Therefore, ethnic Malay students with moderate criteria are not optimal in carrying out the problem-solving ability stage according to Polya.

c) Ethnic Malay With Low Criteria

Ethnic Malay students with low criteria answered questions number 2 and 3 which contained indicators of understanding the problem by writing down the information contained in the questions but not writing down what was asked. And answer question number 1 which also contains indicators of understanding the problem by writing down answers that are not appropriate and are not information from the questions. In the questions that contain indicators for determining plans for ethnic Malay students with low criteria, write down the formulas that will be used in questions number 2 and 3, and in question number 3, ethnic Malay students with low criteria write down the formulas and immediately solve the problem. On the questions that contain indicators that run according to plan, ethnic Malay students only answer questions number 2 and 3. And the answers written by students are not quite right on the results of their calculations. And the last question that contains indicators is to re-examine Malay ethnic students with the criteria of not answering.

Thus, ethnic Malay students with low criteria do not master problem solving skills based on Polya's theory well. In the indicators of understanding the problem, making plans and carrying out according to the plan students answer the questions but the answers written are not correct. On the indicator of re-examining the students did not understand at all. This is also supported by Akbar's research (2018) which states that the problem-solving ability on the indicators of understanding problems and making plans is low and on indicators of running according to plan and re-examining very low.

Based on the explanation above, overall Malay and Chinese ethnic students have the same criteria, namely moderate. However, from every answer written by ethnic Malay and Chinese students, it can be seen that the indicators of preparing a plan, namely writing formulas or steps to solve problems, ethnic Malay students are superior. It can be seen from the students' answers from the criteria for high, medium, and low ethnic Malay students always answer questions that contain indicators for planning. On the indicator of understanding the problem 
of Chinese ethnic students is superior. Where the answers written by ethnic Chinese students on this indicator are almost correct, namely writing the information about the questions in what form is asked and what is known. In the indicators of running according to the plan, ethnic Malay students are superior. It can be seen from the answers written by predetermined steps to obtain the correct final result. And on the indicator of re-examination, there is no superior, either Malay or Chinese. The two ethnic groups are mostly unable to carry out this indicator.

3) Problem Solving Ability Based on Question Type.

Table 4. Average Recapitulation by Type of Question

\begin{tabular}{|c|c|c|c|c|c|c|}
\hline \multirow[t]{3}{*}{ Question Indicator } & \multicolumn{6}{|c|}{ Average } \\
\hline & \multicolumn{3}{|c|}{ Chinese } & \multicolumn{3}{|c|}{ Melay } \\
\hline & 1 & 2 & 3 & 1 & 2 & 3 \\
\hline $\begin{array}{l}\text { Students can identify what } \\
\text { is known from the problem }\end{array}$ & 83,33 & 77,08 & 66,67 & 79,17 & 81,25 & 64,58 \\
\hline $\begin{array}{l}\text { Students can determine the } \\
\text { right way/formula to solve } \\
\text { the problem }\end{array}$ & 62,5 & 72,92 & 68,75 & 77,08 & 72,92 & 77,08 \\
\hline $\begin{array}{l}\text { Students can solve these } \\
\text { problems with correct and } \\
\text { systematic planning }\end{array}$ & 68,75 & 72,92 & 70,83 & 77,08 & 72,92 & 68,75 \\
\hline $\begin{array}{l}\text { Students can double-check } \\
\text { their answers }\end{array}$ & 34,42 & 14,58 & 20,83 & 50 & 10,42 & 10,42 \\
\hline Average & 62,5 & $\mathbf{5 8 , 3 8}$ & 56,77 & $\mathbf{7 0 , 8 3}$ & 59,38 & 55,21 \\
\hline
\end{tabular}

Based on table 4, the average ethnic Chinese and ethnic Malay students were better able to answer the first question than questions number 2 and 3, namely story questions related to everyday problems. Where the average acquisition of question number 1 is a matter of stories related to concepts, for ethnic Chinese students it is 62.5 and ethnic Malays are 70.83. While the average acquisition of story questions related to daily problems for ethnic Chinese students is 59.38 and ethnic Malays is 59.38. And the last question is a matter of stories related to the daily life of the average Chinese ethnic students, namely 56.77, and Malay ethnic students, namely 55.21. Problems related to the concept contain question indicators, namely, students are given story questions related to calculating profit or loss which is a type of question that often appears in routine questions given as an exercise. Questions related to daily life contain question indicators, namely students are given story questions related to calculating the percentage of profit and loss and questions related to everyday life in the general public contain question indicators, namely determining the amount of discount. So based on this analysis, it can be concluded that students still have difficulty when faced with questions related to everyday life because students are only used to the routine questions given. It is described in detail as follows.

The data from this study indicate that ethnic Chinese students and ethnic Malay students are better able to work on problems related to concepts than questions of daily life. This can be seen from the average acquisition of test results given and student answers. It can be seen from the average score of Chinese and Malay ethnic students that the average questions related to concepts are higher than the average questions related to everyday life. The average of questions related to concepts for ethnic Chinese students is 62.5 and for ethnic Malays is 70.83. While the average acquisition of questions related to daily life for ethnic Chinese students is 59.38 and ethnic Malays is 59.38. And the last question related to everyday life in the general public, on average, Chinese ethnic students are 56.77 and ethnic 
Malay students are 55.21. This is because questions related to concepts often appear on routine questions that they usually do compare to questions related to everyday life.

From the answers written by students on questions related to the concept, it is more focused where students write down information about questions, steps for completion to obtain the final results. Compared to questions related to everyday life, both Malay and Chinese ethnic students seem confused about writing answers, so students tend to write down the problem solving of the problem without going through the correct steps. So that some students, both Malay and Chinese, have problems determining the formula or errors in calculations. This is because students do not understand the information about the questions. Based on the discussion above, students still do not master how to do non-routine questions. In line with the opinion of Widodo (in Fatmala, et al, 2020) which states that non-routine questions are still poorly mastered and students tend to follow the way friends solve problems.

4) Differences in Problem Solving Ability.

Table 5. Recapitulation of $\mathbf{T}$. Test Calculations

\begin{tabular}{lllll}
\hline Group & Dk & $\begin{array}{l}\text { Significant } \\
\text { level }\end{array}$ & Account & Ttable \\
\hline $\begin{array}{l}\text { Ethnic Chinese } \\
\text { Ethnic Malay }\end{array}$ & 4 & 0,05 & 1,12 & 2,04 \\
\hline
\end{tabular}

Based on table 6 , it can be seen that $\mathrm{T}_{\text {count }}=1.12$ and $\mathrm{T}_{\text {table }}=2.04$, it means $\mathrm{T}_{\text {count }}<\mathrm{T}_{\text {table, }}$, it can be concluded that Ho is accepted. So that the results obtained are significantly no differences in problem-solving abilities of ethnic Chinese and ethnic Malay students on social arithmetic material. can be described in detail as follows.

The results of research conducted on ethnic Malay and ethnic Chinese students on social arithmetic material at SMP Negeri 1 Singkawang show that there is no significant difference in problem-solving abilities between ethnic Malay and ethnic Chinese students. This can be seen from the results of the problem-solving ability test given to Malay ethnic students and Chinese ethnic students. The results of this problem-solving ability test can be seen from the calculation of the test data with 4 stages of problem-solving abilities carried out using a two-sample independent t-test, where the value of tcount is smaller than table.

The value of tcount is smaller than table because the problem-solving abilities of Malay ethnic students and Chinese ethnic students are on average not much different so that there is no difference in overall problem-solving abilities between Malay ethnic students and Chinese ethnic students. At each stage of problem-solving ability, there is no significant difference. It can be seen that in the first stage, namely understanding the problem: writing important information and questions from the questions of ethnic Chinese students are on high criteria and ethnic Malays are also on high criteria with an average of 75.69 and 75.00. In the second stage, namely determining the plan: writing down the formula that will be used in answering the questions of Chinese students who are on the medium criteria and the Malays are also on the high criteria with an average of 68.06 and 75.69. Furthermore, in the third stage, namely carrying out according to plan: solving problems using a predetermined formula Chinese ethnic students are in high criteria and Malay ethnic students are also in high criteria with an average of 70.83 and 72.92. And finally, in the fourth stage, namely re-checking: re-checking whether the answers from the settlement are correct, Chinese ethnic students are on the low criteria and Malay ethnic students are also on low criteria with an average of 23.61 and 23.61.

It can be seen that at each stage of problem-solving ability there is no significant difference between ethnic Malay students and ethnic Chinese students. So based on the explanation above, it can be seen that there is no significant difference in problem-solving 
abilities between Malay and Chinese ethnic students. This is reinforced by research by Astuti (2009). From the t-test statistic, it can be concluded that the Chinese ethnicity and the Dayak ethnicity have a significant difference in the average score with a probability value of 0.033 ; Likewise, between Dayak ethnicity and Malay ethnicity, there is a significant difference in the average score with a probability value of 0.004 . For the others, there was no significant difference. The meaning of the previous sentence is that there is no significant difference between problem-solving abilities between Chinese and Malay ethnicities.

\section{Conclusion}

The conclusions obtained from the results of this study include:

1) The problem-solving ability of ethnic Chinese students on social arithmetic material is at moderate criteria where students can only work on questions at stage 1) Understanding the problem: writing down important information and questions from the questions; 2) Determine the plan: write down the formula that will be used in answering the question and 3) Implement according to the plan: solve the problem using a predetermined formula.

2) The problem-solving ability of ethnic Malay students on social arithmetic material is in moderate criteria where students can only work on questions at stage 1) Understanding the problem: writing down important information and questions from the problem; 2) Determine the plan: write down the formula that will be used in answering the question and 3) Implement according to the plan: solve the problem using a predetermined formula.

3) Based on the types of questions, Malay and Chinese ethnic students are more able to work on questions related to concepts than questions related to everyday life.

4) There is no significant difference in problem-solving abilities between Chinese and Malay ethnic students.

\section{Recommendation}

Recommendation that can be submitted are; (1) For teachers as a solution to the lack of students' problem-solving abilities, it would be better if the teacher could provide meaningful learning to students. Meaningful learning will create a deep impression on students, so they will be easy to understand the concept. (2) For students, it is expected that in the future they will be able to apply problem-solving skills well in solving social arithmetic problems. So that students can improve their math scores in general on all materials and can be motivated to solve math problems carefully. And (3) for further researchers, it is recommended that further research be carried out to find methods or ways in learning so that students can improve their problem-solving skills so that they can minimize the mistakes they make.

\section{References}

Akbar, P., Hamid, A., Bernard, M., \& Sugandi, A. I. (2018). Analisis Kemampuan Pemecahan Masalah Dan Disposisi Matematika Siswa Kelas XI SMA Putra Juang Dalam Materi Peluang. Journal Cendikia: Jurnal Pendidikan Matematika, 2(1), 144153.

Astuti, D., \& Hudiono, B. (2009). Perilaku Metakognisi Anak Dalam Matematika: Kajian Berdasarkan Etnis dan Gender Pda Siswa SMP di Kalimantan Barat. Seminar Nasional Matematika Dan Pendidikan Matematika, 107-118. Yogyakarta: Universitas Negeri Yogyakarta. 
Bernard, M., Nurmala, N., Mariam, S., \& Rustyani, N. (2018). Analisis Kemampuan Pemecahan Masalah Matematis Siswa SMP Kelas IX Pada Materi Bangun Datar. SJME (Supremum Journal of Mathematics Education), 2(2), 77-83.

Damayanti, R., \& Supriyadi, N. (2016). Analisis Kemampuan Komuniakasi Matematis Siswa Lamban Belajar Dalam Menyelesaikan Soal Bangun Datar. Al-Jabar: Jurnal Pendidikan Matematika, 7(1).

Fajriah, R. S., \& Suryawati. (2016). Analisis Kemampuan Problem Solving dalam Menyelesaikan Materi Aritmatika Sosial Kelas VII SMP Negeri 7 Banda Aceh Tahun Ajaran 2015/2016. Jurnal Ilmiah Mahasiswa Pendidikan Matematika, 1(1), 30-39.

Fatmala, R. R., Sariningsih, R., \& Zhanty, L. S. (2020). Analisis Kemampuan Pemecahan Masalah Matematis Siswa SMP Kelas VII Pada Materi Aritmetika Sosial. Jurnal Cendikia: Jurnal Pendidikan Matematika, 4(1), 227-236.

Hammond. (2000). Ethnomathematics: Concept Definition and Research Perspectives. Columbia University.

Haryani, D. (2011). Pembelajaran Matematika Dengan Pemecahan Masalah Untuk Menumbuh Kembangkan Kemampuan Berpikir Kritis Siswa. Prosiding Seminar Nasional Penelitian, Pendidikan Dan Penerapan MIPA, 121-126. Yogyakarta: Universitas Negeri Yogyakarta.

Ilmiyana, M. (2018). Analisis Kemampuan Pemecahan Masalah Matematis Siswa SMA Ditinjau Dari Tipe Kepribadian Dimensi Myer Briggs Type Indicator (MBTI). Universitas Negeri Islam Raden Intan Lampung.

Islamiah, N., Purwaningsih, W. E., Akbar, P., \& Bernard, M. (2018). Analisis Hubungan Kemampuan Pemecahan Masalah Matematis dan Self Confidence Siswa SMP. Journal of Education, 1(1), 47-57.

Khakim, I. F. (2016). Analisis Kemampuan Pemecahan Masalah Matematika Ditinjau Dari Gaya Kognitif Melalui Model SSCS Dengan Pendekatan Saintifik Pada Siswa Kelas VIII. Universitas Negeri Semarang.

Khalid, M., Saad, S., Hamid, A. S. R., Ibrahim, H., \& Shahrill, M. (2020). Khalid, M., Saad, S., Abdul Hamid, S. R., Abdullah, M. R., Ibrahim, H., \& Shahrill, M. (2020). Enhacing Creativity And Problem Solving Skill Through Creative Problem Solving In Teaching Mathematics. Creativity Studies, 13(2), 270-291.

Lestanti, M. M. (2015). Analisis Kemampuan Pemecahan Masalah Matematika Ditinjau Dari Karakteristik Cara Berpikir Siswa Dalam Model Problem Based Learning. Universitas Negeri Semarang.

Mariyam, P, N. C., \& Wahyuni, R. (2018). Kemampuan Pemecahan Masalah Matematis Siswa Pada Materi Persamaan Linier Satu Variabel Melalui Model Problem Based Learning Berbantuan Modul. Jurnal Pendidikan Matematika Indonesia, 3(2), 66-73.

Moleong, L. J. (2005). Metode Penelitian Kualitatif. Bandung: PT Remaja Rosdakarya.

NCTM. (2000). Principles And Standards For School Mathematics. National Concil Of Teachers Of Matematics. Amerika Serikat: Inc.

Permendikbud. (2016). Peraturan Menteri Pendidikan dan Kebudayaan Nomor 21 Tahun 2016 Tentang Standar Isi Pendidikan Dasar dan Menengah. Jakarta.

Prabawa, E. A., \& Zaenuri. (2017). Analisis Kemampuan Pemecahan Masalah Ditinjau Dari Gaya Kognitif Siswa Pada Model Project Based Learning Bernuansa Etnomatematika. Unnes Journal of Mathematics Education Research, 6(1), 120-129.

Putra, H. D., Thahiram, N. F., Ganianti, M., \& Nuryana, D. (2018). Kemampuan Pemecahan Masalah Matematis Siswa SMP pada Materi Bangun Ruang. JIPM (Jurnal Ilmiah Pendidikan Matematika), 6(2), 82-90. 
Rofiqoh, Z. (2015). Analisis Kemampuan Pemecahan Masalah Matematika Siswa Kelas X Dalam Pembelajaran Discovery Learning Berdasarkan Gaya Belajar Siswa. Universitas Negeri Semarang.

Sari, P. N., \& Dewi, S. F. (2020). Prasangka Terhadap Etnis Tionghoa di Parimanan. Journal of Civic Education, 3(2), 165-171.

Sudjana, N., \& Ibrahim. (2007). Penelitian Dan Penilaian Pendidikan. Bandung: Sinar Baru Algesisndo.

Suprapto, W., \& Kariadi, D. (2017). Kontestasi Etnis Di Kancah Politik (Ethnic Contestation In Political Scope). Jurnal Sosial Humaniora, 8(2), 99-125.

Utami, R. W., \& Wutsqa, D. U. (2017). Analisis Kemampuan Pemecahan Masalah Matematis dan Self-Efficacy Siswa SMP Negeri Di Kabupaten Ciamis. Jurnal Riset Pendidikan Matematika, 4(2), 166-175. 